Original Paper

\title{
The Combustion System Emitting Only Pure Carbon Dioxide by Using Molten Salt's Redox Couples
}

\author{
Satoshi SHIMANO*1, and Shukuji ASAKURA*2 \\ (Received January 20, 2004) \\ 純粋な二酸化炭素の回収が可能になる溶融塩レドックス燃焼システム \\ 島野 哲*1, 朝倉祝治*2
}

The authors proposes an innovative technology "Molten Salt Redox Combustion Energy System", that includes the flameless combustion in molten salt. This system generates a high temperature without discharging pollutants coming from combustion of fuels. At the same time, it is possible to recover the pure carbon dioxide.

This system characterized by coupling two redox reactions occurring at different places, separately. At one place, the oxidation of the redox couple by air proceeds, while at the other, the reduction reaction with fuels does.

This system is ready for giving the following advantages.

- Pure carbon dioxide from the combustion of fuels can be recovered.

- Thermal NOx is not generated, because of relatively low temperature reactions.

- Sulfur, nitrogen and chlorine compounds in fuels are caught in molten salt as sulfates, nitrates and chlorides of alkali metals.

- The mix fuels of a variety of compositions can be applied.

- A few kinds of oxidation-reduction couples can provide the chemical heat pump effect.

As the first step of developing this combustion system, the authors describe the theoretical concept and discusses it feasibility based on the chemical thermodynamics. The promising redox couples were found successfully.

\section{Key Words}

Molten salt, Combustion system, Recovering carbon dioxide

\section{1. 緒 言}

地球温暖化防止の観点から，二酸化炭素の排出量を削隇す ることが急務となっている。二酸化炭素の大量発生源は大型 の化石燃料の燃焼装置であり，例えば電力を供給する火力発 電所や工業製品を製造に利用する産業用ボイラである。

近年，装置のエネルギー効率の向上させるなど二酸化炭素 の発生量の削減に努めると共に，排出された二酸化炭素を海 中や地中に固定隔離させることが考えられている。ただし，従

* 1 Graduate School of Engineering,

Yokohama National University

79-5 Tokiwadai, Hodogaya-ku, Yokohama-shi, Kanagawa 240-8501, Japan

* 2 Faculty Engineering, Yokohama National University 79-5 Tokiwadai, Hodogaya-ku, Yokohama-shi, Kanagawa 240-8501, Japan
来型の燃焼装置から排出される二酸化炭素は，燃焼に必要な 空気と混合されて, その成分である窒素により十数 $v 01 \%$ に希 薄化される。海洋や地中へと隔離するためには排出ガス中か ら分離して, 純粋な二酸化炭素として回収しなければならな い。燃焼排出ガス中からの二酸化炭素の分離・回収手法とし て, 分離膜法, 吸着法, 化学吸収法が考案されているが, 多 大なエネルギーが必要であり，コストが嵩むことが難点で あった1)。また従来とは燃焼方法を変えることで, 二酸化炭素

* 1 横浜国立大学大学院工学府 干 240-8501 神奈川県横浜市保土ヶ谷区常盤台 79-5

*2 横浜国立大学大学院工学研究院 干 240-8501 神奈川県横浜市保土ヶ谷区常盤台 79-5 


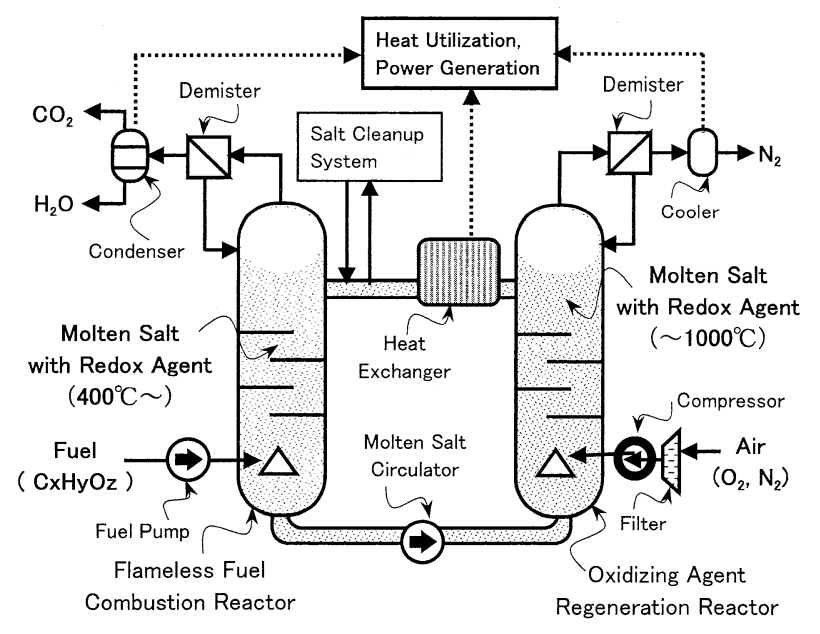

Fig. 1 Molten Salt Redox Combustion System

が純度の高い状態で燃焼排ガスとして直接排出される方法と して純酸素燃焼法 ${ }^{2)}$ や媒体循環燃焼法 ${ }^{3)}$-5) が提案されている。 我々は溶融塩中での酸化還元反応を利用することで, 燃料 の燃焼を進行しながら, 発生する二酸化炭素を直接回収する ことが可能となり, かつ窒素酸化物や硫黄酸化物などの污染 物質を発生させずに，高温熱エネルギーを利用できる燃焼方 法として溶融塩レドックス燃焼システム6 を考案した。Fig. 1 に本システムの概略を示す。本燃焼システムの反応器は酸化 剤生成部と無炎燃焼部の二つの反応容器から構成される。こ れらの反応器内に酸化還元媒体を含む溶融塩で満たされ, こ れを循環させる。燃焼に必要な燃料は無炎燃焼部へと, 空気 は酸化剂生成部へと別々に導入される。空気と燃料が直接混 合することがないため, 燃焼により発生する二酸化炭素が空 気中の窒素に薄められることはない。そのため純度の高い二 酸化炭素を直接回収できることが特徵である。本システムで は高温の溶液である溶融塩中で生ずる酸化還元反応を利用し て, 火炎を伴わずに, 燃料を燃焼する。さらに, 溶融塩の種 類を選ぶことで, 硫黄分, 窒素分, 塩素分を溶融塩に捕捉す ることが可能になるため, これらの成分を含む石炭や廃棄物 を燃焼させても硫黄酸化物, 窒素酸化物やダイオキシンなど の環境污染物質を発生させないことも特徴である。

本論文では, 本システムの原理と特徵について述べる。さ らに本燃焼システムに必要不可欠である溶融塩中における酸 化還元反応を利用した燃焼方法について, その実現可能性を, 熱力学を基にした理論的検討より見出したので報告する。

\section{2. 従来の研究}

\section{1 純粋な二酸化炭素を回収できる燃焼方法}

従来の燃焼方法では，燃焼により発生する二酸化炭素は酸 化剂として利用する空気の主成分である窒素により希釈され るため排ガス中では十数Vol\%である。温室効果ガスである二 酸化炭素を海洋や地中への隔離や, 有効利用のためには, 排 ガス中から濃縮して分離することが必要であるが, そのコス トが多大であることが問題であった。そこで，従来の燃焼方 法とは異なり, 濃度の高い二酸化炭素が直接排出される燃焼
方法として純酸素燃焼法や媒体循環燃焼法が提案されている。 純酸素燃焼法 ${ }^{2)}$ は, 助燃剤として空気ではなく純酸素を利 用するものである。燃焼生成物として，二酸化炭素と水蒸気 のみが，空気中の窒素に希釈されることなく，発生する。水 蒸気を凝縮することで, 純粋な二酸化炭素を回収できる。さ らに高温度を利用しても，窒素酸化物の発生がないという利 点がある。しかし，純酸素の製造に多大なエネルギーを必要 とすることが問題である。

媒体循環燃焼法 ${ }^{3 \dagger}$-5) の特徵は，金属粒子を媒体として，燃 焼を空気が反応する酸化工程と燃料が反応する還元工程とに 分けることである。媒体となる金属粒子にはニッケルや鉄が 提案されている。酸化工程では，空気と金属粒子が反応し金 属酸化物を生成する。そして還元工程に金属酸化物のみを輸 送し，ここで炭化水素など燃料と反応させるのである。この とき，空気と燃料が直接混合されることがないため，燃焼で 生成する二酸化炭素と水蒸気が，窒素により希釈されること はない。この燃焼方法では効率の向上が見达まれている。反 応温度を火炎の発生温度よりも低く抑えられることから， Thermal NOx が発生しないことも見达まれている。現在，反 応特性解析，金属粒子の設計および流動特性の検討，プロ七 スのエネルギー解析などの実用化に向けた基礎的な検討が行 われている。

この燃焼方法で利用できる燃料としては，炭化水素や一酸 化炭素のガス状の然料であり, 固体や液体についてはガス化 して利用することになる。また，硫黄分などを含む燃料では 脱硫装置が別に必要になると考えられる。

\section{2 廃棄物や石炭の溶融塩による処理}

溶融塩を利用した廃菓物の燃焼処理もしくは燃料の改質方 法として溶融塩酸化法7) 11) が提案されている。この処理方法 では特に炭酸塩を基礎とした溶融塩を利用することで，硫黄 分, 窒素分, 八ロゲン化物を溶融塩に化学的に安定に取り込 むことが可能であり, 硫黄酸化物, 窒素酸化物, 塩化水素, ダ イオキシンなどの有害物質を発生することはない。溶融炭酸 塩中で生じる反応を解析する基礎研究 ${ }^{12)}$ - 15) とともに実用化 に向けた研究 ${ }^{16)}$-21) が行われている。ベンチスケールの装置 では木材16j, 硫黄分を多量に含むゴムやイオン交換樹脂16177),

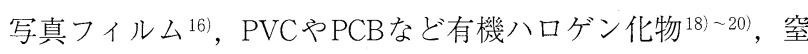
素分を含む爆薬 ${ }^{21}$, DDT な゙の農薬 ${ }^{221}$, サリンなどの化学兵 器23) どの廃裹物の処理が行われ，良好な処理効率を有害ガ スが発生せずに処理できることや，さらに処理に伴って発生 する一酸化炭素や水素等の燃料ガスを回収できることが報告 されている。また溶融塩酸化法は石炭を脱硫しながら一酸化 炭素や水素へと改質するガス化法 ${ }^{24)}$ としての利用も考えられ た。さらに溶融塩を利用した排煙からの脱硫，脱硝プロセス であるBattelle-Northwestプロセス ${ }^{25)}$ や溶融炭酸塩による排煙 脱硫プロセス ${ }^{26)}$ も提案されている。

溶融塩酸化法では燃焼により発生する二酸化炭素は, 空気 中の窒素により希薄化されるため, 回収には分離工程が必要 である。 
3. 溶融塩レドックス燃焼システムの原理とその実現可能性 3.1 溶融塩中の酸化還元反応を利用した燃焼反応

溶融塩レドックス燃焼システムに扔ける燃焼は, 酸化還元 媒体を含む溶融塩中において, 空気中の酸素を反応させる酸 化剂生成反応と, 燃料を反応させる無炎燃焼反応の二段階の 化学反応過程を経て完結する。これらの反応は, それぞれ酸 化剂生成部と無炎燃焼反応部で行われる。反応器は酸化還元 媒体を含む溶融塩で満たされており, 溶融塩を流動させるこ とで二つの反応器に酸化体および還元体が循環する。酸化剂 生成反応とは, 溶融塩中に含まれている酸化還元媒体の還元 体 $\mathrm{R}$ を空気により酸化し, 酸化体 $\mathrm{RO}$ m 生成する反応 (1)で ある。

$$
n R+\frac{m \cdot n}{2} O_{2} \rightarrow n R O_{m}
$$

溶融塩の循環により, 酸化刘生成部で生成した ROmは無炎燃 料反応部へと輸送される。ここでは溶融塩に燃料 $\left(\mathrm{C}_{\mathrm{x}} \mathrm{H}_{\mathrm{y}} \mathrm{O}_{z}\right)$ を 投入することで，反応 $(2)$ に示す無炎燃料反応が生ずる。

$$
\mathrm{C}_{\mathrm{x}} \mathrm{H}_{\mathrm{y}} \mathrm{O}_{z}+n R \mathrm{O}_{m} \rightarrow \mathrm{nR}+\mathrm{xCO}+\frac{\mathrm{y}}{2} \mathrm{H}_{2} \mathrm{O}
$$

ここで, $\mathrm{x}, \mathrm{y}, \mathrm{z}$ はそれぞれ燃料中の炭素, 水素, 酸素の組成 であり，mは酸化還元媒体の 1 分子の $\mathrm{R}$ が $\mathrm{ROm}$ になる際に受 け取る酸素原子数である。そして $\mathrm{n}$ は燃料の原子価に配慮し て決まる酸化体の分子数であり, ここでは $n=\frac{2 x+\frac{y}{2}-Z}{m}$ と なる。無炎燃焼反応で生じた R は溶融塩により酸化刘生成部 に輸送することで循環利用される。このため, 反応 (1) と (2) より反応で示す燃料の燃焼と等価になる。

$$
\mathrm{C}_{\mathrm{x}} \mathrm{H}_{\mathrm{y}} \mathrm{O}_{z}+\frac{m \cdot n}{2} \mathrm{O}_{2} \rightarrow \mathrm{x} \mathrm{CO}_{2}+\frac{y}{2} \mathrm{H}_{2} \mathrm{O}
$$

すなわち, 溶融塩と酸化還元媒体は燃焼の進行で, 消費され ることはないのである。

\section{2 熱力学を基にした実現可能な酸化還元系の探索}

本システムの実現には, 溶融塩中での酸化還元反応により, 燃料の燃焼を進行させる酸化還元対 $\mathrm{ROm} / \mathrm{R}$ が必要である。そ こで最初に熱力学計算により $\mathrm{RO} / \mathrm{m}$ の対を探索した。すなわ ち反応 $(1)$ の酸化剂生成反忘と反応 $(2)$ の無炎燃焼反応とが, 両方進行する $\mathrm{ROm} / \mathrm{R}$ の対を選定するのである。酸化剂生成反 応では, Rが空気により酸化されて $\mathrm{ROm}$ を形成すること, そ して無炎燃焼反応では, $\mathrm{RO}$ m が燃料を酸化して再び $\mathrm{R} を$ 形成 する能力を持っていること, という二つの条件を満たさなく てはならない。すなわち対象とする $\mathrm{RO} / \mathrm{m} / \mathrm{R}$ の対の酸化力は, 空気より小さく，かつ燃料よりも大きいことが必要であると 言い換えることができる。そこで候補とされる様々な酸化物 やオキソ酸塩の酸化還元対の酸化力と, 空気や燃料の酸化力 とを比較した。

ここでは酸化還元対と空気および燃料の酸化力を, 酸素の 酸化力を基準として, 各酸化還元対と酸素との平衡における 酸素分圧で比較した。

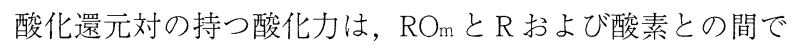
成り立つ(4)で表される平衡を考慮する。この平衡定数 $K_{R O} / R$
は(5)式で表される。

$$
\begin{gathered}
\frac{2}{m} R O_{m} \rightleftarrows \frac{2}{m} R+O_{2} \\
K_{R O m / R}=\frac{a_{R}^{\frac{2}{m}} \cdot P\left(O_{2}\right)}{a_{R O m}^{\frac{2}{m}}}
\end{gathered}
$$

ここで $a_{R n O m}$ と $a_{R}$ はそれぞれ $\mathrm{Rn}_{\mathrm{n}} \mathrm{m}$ と $\mathrm{R}$ の活量であり，P(O $\left.\mathrm{O}_{2}\right)$ は 酸素分圧である。また平衡定数 $K R O M / R$ は各物質の化学ポテン シャルより計算される。

酸化還元対の平衡に打ける酸素分圧は, 便宜上(5)式の常用 対数を取って，(6)式で表される。

$$
\log P\left(O_{2}\right)_{R O m / R}=\log K_{R O m / R}+\log \frac{a_{R O m}^{\frac{2}{m}}}{a_{R}^{\frac{2}{m}}}
$$

$\mathrm{RO} / \mathrm{R}$ の対の酸化力は (6) 式で与えられる $\log P\left(\mathrm{O}_{2}\right)_{R \mathrm{Om} / \mathrm{R}}$ を指 標として比較することができる。ここで $\log P\left(O_{2}\right)_{R O m / R}$ は, 熱 力学デー夕より計算される $\log K_{R O m / R}$ 以外に, ROmとRの活量 比により変化する。 $\mathrm{ROm}$ と $\mathrm{R}$ が金属や酸化物で固体状態であ るとき, それぞれの活量が 1 となるため, (6)式の右辺第二項 は 0 になり, $\log P\left(\mathrm{O}_{2}\right)_{\mathrm{RO} / \mathrm{m}}$ と $\log K_{R \mathrm{O} / \mathrm{R}}$ は等しくなる。またROm やRが液体ではその活量比に応じて $\log P\left(O_{2}\right)_{R O m} /$ は変化する。 各酸化還元対を比較するにあたっては，活量項を考慮せずに， 物質によって大きく变化する $\log K_{R O m} / R$ 項のみで比較する。対 象とする $\mathrm{RO} / \mathrm{R}$ の対について, $\log K_{R O m / R}$ の值が大きいほど, 平衡(4)における酸素分圧が大きく, 酸化力が大きいことを示 守。

また燃料 $\mathrm{C}_{\mathrm{x}} \mathrm{H}_{\mathrm{y}} \mathrm{O}_{z}$ の酸化力に関しては, 対象とする $\mathrm{C}_{\mathrm{x}} \mathrm{H}_{\mathrm{y}} \mathrm{O}_{\mathrm{z}}$ と 酸素および燃焼生成物である二酸化炭素と水蒸気における平 衡を, 平衡(4) と同様に, 右辺で酸素の化学量論数が 1 となる ようにして考慮する。一般的には平衡(7)で表され， $\mathrm{C}_{\mathrm{x}} \mathrm{H}_{\mathrm{y}} \mathrm{O}_{\mathrm{z}}$ の

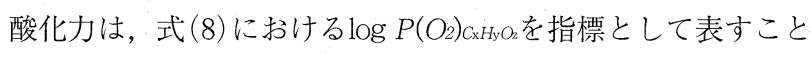
ができる。

$$
\begin{aligned}
& \frac{2 x}{2 x+\frac{y}{2}-z} \mathrm{CO}_{2}+\frac{y}{2 x+\frac{y}{2}-z} \mathrm{H}_{2} \mathrm{O} \rightleftarrows \frac{2}{2 x+\frac{y}{2}-z} \mathrm{C}_{x} \mathrm{H}_{y} \mathrm{O}_{z}+\mathrm{O}_{2}(7)
\end{aligned}
$$

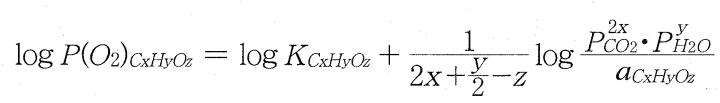

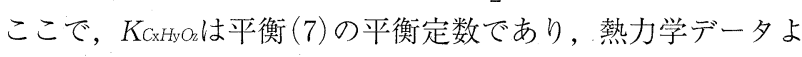
り計算される。そして $\mathrm{CO}_{\mathrm{CO}}$ と $P_{\mathrm{H} 2 \mathrm{O}}$ は二酸化炭素および水蒸気

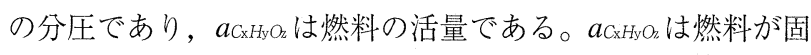
体の場合では 1 であり, 気体では分圧である。酸化還元対と の酸化力を比較する際には, 対象とする酸化還元対で大きく 変化する $\log K \mathrm{C}_{\mathrm{X} H \mathrm{H}} \mathrm{O}_{\mathrm{L}}$ 項のみを考慮する。

また空気の酸化力は, 空気中の酸素の分圧が $0.2 \mathrm{~atm}$ である ので, 平衡定数は $\log K_{\text {Air }}=\left.\log P\left(O_{2}\right)\right|_{\text {Air }}=\log (0.2)=-0.70$ で ある。

以上の方法により, 熱力学データより算出した $\log K_{R O m} / R$ と

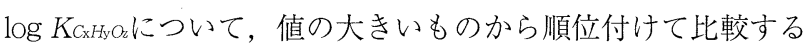
ことで, 本システムの条件に適した $\mathrm{ROm} / \mathrm{R}$ を探索した。対象 とする酸化還元対の $\log K_{R O \mathrm{~m} / R}$ と燃料の $\log K_{\mathrm{C}_{\mathrm{x}} \mathrm{H}_{\mathrm{y}} \mathrm{a}}$ は, 温度に より変化し，その順位も変動する。温度は燃焼により発生す る熱を利用することを想定し，1027ㄷとした。Table 1でlog $K_{R O M / R}$ と $\log K_{\mathrm{C}_{\mathrm{X} H} \mathrm{O}_{2}}$ の值を大きい順, すなわち酸化力の大きい 
Table 1 Oxidation potentials of Redox couples of oxides, oxyanions and organic matters as fuels

\begin{tabular}{|c|c|c|c|c|c|c|c|}
\hline No. & $\mathrm{ROm}$ & $\mathrm{R}$ & $\begin{array}{l}\log K_{R O_{n} / R} \\
\log K_{C_{x} H_{y} O_{z}}\end{array}$ & No. & $\mathrm{RO}_{\mathrm{m}}$ & $\mathrm{R}$ & $\begin{array}{l}\log K_{R O_{m} / R} \\
\log K_{C_{x} H_{y} O}\end{array}$ \\
\hline 1 & $\mathrm{Li}_{2} \mathrm{O}_{2}$ & $\mathrm{Li}_{2} \mathrm{O}$ & 5.2 & 24 & $\mathrm{ReO}_{2}$ & $\operatorname{Re}$ & -8.2 \\
\hline 2 & $\mathrm{TbO}_{2}$ & $\mathrm{~Tb}_{2} \mathrm{O}_{3}$ & 3.7 & 25 & $\mathrm{Sb}_{4} \mathrm{O}_{6}$ & $\mathrm{Sb}$ & -9.8 \\
\hline 3 & $\mathrm{Tl}_{2} \mathrm{O}_{3}$ & $\mathrm{Tl}_{2} \mathrm{O}$ & 0.9 & 26 & $\mathrm{NiO}$ & $\mathrm{Ni}$ & -9.9 \\
\hline 4 & $\mathrm{Mn}_{2} \mathrm{O}_{3}$ & $\mathrm{Mn}_{3} \mathrm{O}_{4}$ & 0.3 & 27 & $\mathrm{Fe}_{2} \mathrm{O}_{3}$ & $\mathrm{FeO}$ & -10.2 \\
\hline 5 & $\mathrm{Rh}_{2} \mathrm{O}_{3}$ & Rh & -0.4 & 28 & $\mathrm{CoO}$ & $\mathrm{Co}$ & -11.5 \\
\hline 6 & Air & - & -0.7 & 29 & $\mathrm{SnO}$ & $\mathrm{Sn}$ & -12.2 \\
\hline 7 & $\mathrm{AmO}_{2}$ & $\mathrm{Am}_{2} \mathrm{O}_{3}$ & -0.7 & 30 & $\mathrm{Na}_{2} \mathrm{SO}_{4}$ & $\mathrm{Na}_{2} \mathrm{~S}$ & -12.2 \\
\hline 8 & $\mathrm{RbO}_{2}$ & $\mathrm{Rb}_{2} \mathrm{O}_{2}$ & -0.8 & 31 & $\mathrm{SnO}_{2}$ & $\mathrm{SnO}$ & -12.4 \\
\hline 9 & $\mathrm{CuO}$ & $\mathrm{Cu}_{2} \mathrm{O}$ & -1.0 & 32 & $\mathrm{WO}_{3}$ & $\mathrm{WO}_{2}$ & -12.6 \\
\hline 10 & $\mathrm{Rb}_{2} \mathrm{O}_{2}$ & $\mathrm{Rb}_{2} \mathrm{O}$ & -1.3 & 33 & $\mathrm{GeO}_{2}$ & $\mathrm{Ge}$ & -13.3 \\
\hline 11 & $\mathrm{Cs}_{2} \mathrm{O}_{2}$ & $\mathrm{Cs}_{2} \mathrm{O}$ & -1.4 & 34 & $\mathrm{In}_{2} \mathrm{O}_{3}$ & In & -13.6 \\
\hline 12 & $\mathrm{UO}_{3}$ & $\mathrm{UO}_{2}$ & -1.6 & 35 & $\mathrm{CO}_{2}$ & $\mathrm{CO}$ & -13.6 \\
\hline 13 & $\mathrm{IrO}_{2}$ & Ir & -2.0 & $\overline{36}$ & $\mathrm{H}_{2} \mathrm{O}$ & $\underline{\mathrm{H}_{2}}$ & -14.1 \\
\hline 14 & $\mathrm{~V}_{2} \mathrm{O}_{5}$ & $\mathrm{~V}_{2} \mathrm{O}_{4}$ & -3.0 & 37 & $\mathrm{MoO}_{2}$ & Mo & -14.3 \\
\hline 15 & $\mathrm{RuO}_{2}$ & $\mathrm{Ru}$ & -3.4 & 38 & $\mathrm{WO}_{2}$ & W & -14.3 \\
\hline 16 & $\mathrm{TeO}_{2}$ & $\mathrm{Te}$ & -3.5 & 39 & $\mathrm{FeO}$ & $\mathrm{Fe}$ & -14.5 \\
\hline 17 & $\mathrm{Tl}_{2} \mathrm{O}$ & $\mathrm{Tl}$ & -4.8 & $\underline{40}$ & $\mathrm{CO}_{2}$ & $\underline{\mathrm{C}}$ & -15.9 \\
\hline 18 & $\mathrm{Mn}_{3} \mathrm{O}_{4}$ & $\mathrm{MnO}$ & -5.6 & $\underline{42}$ & $\mathrm{H}_{2} \mathrm{O}, \mathrm{CO}_{2}$ & $\underline{\mathrm{CH}}_{4}$ & -16.1 \\
\hline 19 & $\mathrm{Cu}_{2} \mathrm{O}$ & $\mathrm{Cu}$ & -5.9 & 44 & $\mathrm{Na}_{2} \mathrm{UO}_{4}$ & $\overline{\mathrm{Na}_{3} \mathrm{UO}} 4$ & -16.5 \\
\hline 20 & $\mathrm{Bi}_{2} \mathrm{O}_{3}$ & $\mathrm{Bi}$ & -6.0 & 45 & $\mathrm{Nb}_{2} \mathrm{O}_{5}$ & $\mathrm{NbO}_{2}$ & -16.8 \\
\hline 21 & $\mathrm{MoO}_{3}$ & $\mathrm{MoO}_{2}$ & -6.3 & 46 & $\mathrm{Ga}_{2} \mathrm{O}_{3}$ & $\mathrm{Ga}$ & -17.8 \\
\hline 22 & $\mathrm{PbO}$ & $\mathrm{Pb}$ & -7.5 & 47 & $\mathrm{CeO}_{2}$ & $\mathrm{Ce}_{2} \mathrm{O}_{3}$ & -18.0 \\
\hline 23 & $\mathrm{~V}_{2} \mathrm{O}_{4}$ & $\mathrm{~V}_{2} \mathrm{O}_{3}$ & -7.9 & $\underline{50}$ & $\mathrm{H}_{2} \mathrm{O}, \mathrm{CO}_{2}$ & $\mathrm{CH}_{3} \mathrm{OH}$ & -19.8 \\
\hline
\end{tabular}

順，に並べて比較した。このとき $\log K_{R O m / R}$ と $\log K_{\mathrm{C}_{x} H_{\mathrm{y}} \mathrm{O}}$ の計 算には対象物質の設定温度における純物質の相状態における 熱力学データ27)を用いて計算した。

酸化剂生成反応については $\log K_{R O m / R}$ が $\log K_{\text {Air }}=-0.70$ より も小さいことが必要である。Table 1では空気の酸化力の順位 はNo. 6 である。空気より酸化力の大きいNo. 1～5の酸化還 元対は，酸化剂生成反応が進行しないため, $\mathrm{RO} \mathrm{m}$ が生成され ないことから本システムに利用できない。No.7以降の酸化還 元対は, 空気との反応による酸化剂生成反応の進行が見込ま れる。

Table 1では燃料として, 水素, メタン, 一酸化炭素とメ夕 ノールを考慮した。これらは, 表中の順位抢よび然料に下線 で示した。1027ㄷでは燃料の中で最も酸化力が大きいものは 一酸化炭素であり，その順位はNo. 35 である。これより酸化 力の小さい酸化還元対では, 一酸化炭素を二酸化炭素に酸化 する能力がないため, 本システムに適さない。No.34以上の酸 化還元対では，その酸化体により考慮した燃料を酸化できる ことが見込まれる。

以上より本システムに適用が見込まれる酸化還元対として は, No. $7 〜 34$ が挙げられる。Table 1 において, これらは その順位を四角で囲んで示した。溶融塩中でこれらの酸化還 元対を実際に形成できれば，本システムに必要不可欠である 溶融塩中での燃焼を実現することが可能になる。

ここでの予測は, 熱力学を基にしており, 反応の進行の可
能性を示した。たたし，その反応速度に関しては実験により 確認する必要がある。特に金属や金属酸化物を酸化還元媒体 に含むものについては，シンタリングによる表面積の低下に より, 反応速度の低下する可能性がある。そこでシンタリン グの防止として, 酸化還元媒体を担体に担持させる方法を一 つの有効な手段と考えている。

我々の研究では, 実験室規模の反応器を用いて, 無炎燃焼 反応と酸化剂生成反応について, 別々に反応を検討した。そ の結果, 特に $\mathrm{Na}_{2} \mathrm{SO}_{4} / \mathrm{Na}_{2} \mathrm{~S} に お い て$ 溶融塩中で無炎燃焼反応

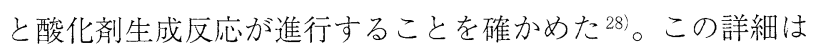
別の報文に示す。

\section{4. 溶融塩レドックス燃焼システムよるケミカルヒートポンプ 作用}

\section{1 反応に伴う熱量の酸化還元系による違い}

本システムでは, 酸化剤生成反応と無炎燃焼反応における 反応熱の和は燃焼熱となるが，燃焼に利用する $\mathrm{ROm} / \mathrm{R} に よ り ，$ それぞれの反応における反応熱が異なる。燃料として炭素を 燃焼させたときの無炎燃焼反応および酸化剤生成反応の反応 熱をTable 2 に示す。Table 2 に示す酸化還元対は前項に示し た理論計算で, 対象とする温度において, 各反応の実現可能

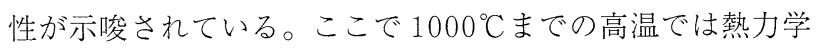
デー夕がなかった $\mathrm{Na}_{2} \mathrm{O}_{2} / \mathrm{Na}_{2} \mathrm{O}$ と $\mathrm{NaNO}_{3} / \mathrm{NaNO}_{2}$ に関しては, それぞれ $\mathrm{Na}_{2} \mathrm{O}_{2} / \mathrm{Na}_{2} \mathrm{O}$ では $647^{\circ} \mathrm{C}$ 未満に扔いて, $\mathrm{NaNO}_{3} / \mathrm{NaNO}_{2}$ では $727^{\circ} \mathrm{C}$ 未満において, 各反応の実現可能性が見出されてい る。Table 2で示した酸化還元対では, すべて酸化剤生成反応 は発熱であった。同じ燃料を溶融塩中で燃焼したときでも, 利 用する酸化還元対により, 無炎燃焼反応および酸化剂生成反 応の反応熱が大きく異なることが明らかとなった。

\section{2 ケミカルヒートポンプ作用とその効率}

無炎燃焼反応が吸熱反応である酸化還元系では, 酸化剂生 成反応は炭素と酸素の直接燃焼の発熱量よりも発熱量が大き くなる。Table 2に示した酸化還元対としては $\mathrm{Fe}_{2} \mathrm{O}_{3} / \mathrm{FeO}, \mathrm{CoO} /$ $\mathrm{Co}, \mathrm{NiO} / \mathrm{Ni}, \mathrm{SnO} / \mathrm{SnO}_{2}, \mathrm{WO}_{3} / \mathrm{WO}_{2}, \mathrm{Na}_{2} \mathrm{SO}_{4} / \mathrm{Na}_{2} \mathrm{~S}$ が挙げられ る。これらの酸化還元対については, 燃料の燃焼と同時にケ ミカルヒートポンプを利用することで, 通常の燃焼方法より も多くの高温熱の回収が可能でとなる。

ケミカルヒートポンプ作用を利用するには，酸化剂生成部 の温度を無炎燃焼部よりも高くする必要がある。酸化剂生成

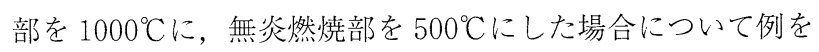
示す。無炎燃焼部の温度は, 溶融塩として二酸化炭素の存在 下で安定な溶融炭酸塩の共晶塩 $\mathrm{Li}_{2} \mathrm{CO}_{3}-\mathrm{Na}_{2} \mathrm{CO}_{3}-\mathrm{K}_{2} \mathrm{CO}_{3}$ ( $43.5 \mathrm{~mol}$ \%-31.5-25.0, 融点 $\left.397^{\circ} \mathrm{C}\right)$ の融点を考慮し, これよりも十分に 高い温度として設定した。

無炎燃焼反応の吸熱により，500 Cの熱源から熱を吸収させ

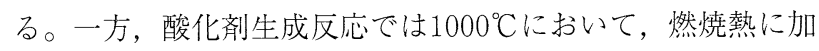
えて, 無炎燃焼反応で吸熱した熱が発生する。つまり無炎燃 焼反応により $500^{\circ} \mathrm{C}$ で吸熱された熱を, 酸化剂生成反応でより 価值の高い $1000^{\circ} \mathrm{C}$ 熱として再利用することができるのであ 
Table 2 Heat of Oxidizing agent regeneration reactions and Flameless fuel combustion reactions for combustion of graphite as fuel

\begin{tabular}{|c|c|c|c|}
\hline \multirow{2}{*}{$\begin{array}{c}\text { Redox System } \\
\text { Ox/Red }\end{array}$} & \multirow{2}{*}{$\begin{array}{c}\text { Reactions } \\
\text { Oxidizing agent regeneration } \\
\text { Flameless fuel combustion }\end{array}$} & \multicolumn{2}{|c|}{$\Delta \mathrm{H}^{0}(\mathrm{~kJ} / \mathrm{mol})$} \\
\hline & & $500^{\circ} \mathrm{C}$ & $1000^{\circ} \mathrm{C}$ \\
\hline \multirow{2}{*}{$\mathrm{Na}_{2} \mathrm{O}_{2} / \mathrm{Na}_{2} \mathrm{O}$} & $2 \mathrm{Na}_{2} \mathrm{O}+\mathrm{O}_{2} \rightarrow 2 \mathrm{Na}_{2} \mathrm{O}_{2}$ & -182 & - \\
\hline & $\mathrm{C}+2 \mathrm{Na}_{2} \mathrm{O}_{2} \rightarrow \mathrm{CO}_{2}+2 \mathrm{Na}_{2} \mathrm{O}$ & -212 & - \\
\hline \multirow{2}{*}{$\mathrm{V}_{2} \mathrm{O}_{5} / \mathrm{V}_{2} \mathrm{O}_{4}$} & $2 \mathrm{~V}_{2} \mathrm{O}_{4}+\mathrm{O}_{2} \rightarrow 2 \mathrm{~V}_{2} \mathrm{O}_{5}$ & -276 & -140 \\
\hline & $\mathrm{C}+2 \mathrm{~V}_{2} \mathrm{O}_{5} \rightarrow \mathrm{CO}_{2}+2 \mathrm{~V}_{2} \mathrm{O}_{4}$ & -118 & -255 \\
\hline \multirow{2}{*}{$\mathrm{Mn}_{2} \mathrm{O}_{3} / \mathrm{MnO}$} & $4 \mathrm{MnO}+\mathrm{O}_{2} \rightarrow 2 \mathrm{Mn}_{2} \mathrm{O}_{3}$ & -375 & -363 \\
\hline & $\mathrm{C}+2 \mathrm{Mn}_{2} \mathrm{O}_{3} \rightarrow \mathrm{CO}_{2}+4 \mathrm{MnO}$ & -19 & -32 \\
\hline \multirow{2}{*}{$\mathrm{Fe}_{2} \mathrm{O}_{3} / \mathrm{FeO}$} & $4 \mathrm{FeO}+\mathrm{O}_{2} \rightarrow 2 \mathrm{Fe}_{2} \mathrm{O}_{3}$ & -575 & -558 \\
\hline & $\mathrm{C}+2 \mathrm{Fe}_{2} \mathrm{O}_{3} \rightarrow \mathrm{CO}_{2}+4 \mathrm{FeO}$ & +181 & +162 \\
\hline \multirow{2}{*}{$\mathrm{CoO} / \mathrm{Co}$} & $2 \mathrm{CO}+\mathrm{O}_{2} \rightarrow 2 \mathrm{CoO}$ & -468 & -467 \\
\hline & $\mathrm{C}+2 \mathrm{CoO} \rightarrow \mathrm{CO}_{2}+2 \mathrm{Co}$ & +74 & +72 \\
\hline \multirow{2}{*}{$\mathrm{NiO} / \mathrm{Ni}$} & $2 \mathrm{Ni}+\mathrm{O}_{2} \rightarrow 2 \mathrm{NiO}$ & -472 & -467 \\
\hline & $\mathrm{C}+2 \mathrm{NiO} \rightarrow \mathrm{CO}_{2}+2 \mathrm{Ni}$ & +78 & +72 \\
\hline \multirow{2}{*}{$\mathrm{CuO} / \mathrm{Cu}_{2} \mathrm{O}$} & $2 \mathrm{Cu}_{2} \mathrm{O}+\mathrm{O}_{2} \rightarrow 4 \mathrm{CuO}$ & -281 & -270 \\
\hline & $\mathrm{C}+4 \mathrm{CuO} \rightarrow \mathrm{CO}_{2}+2 \mathrm{Cu}_{2} \mathrm{O}$ & -113 & -125 \\
\hline \multirow{2}{*}{$\mathrm{MoO}_{3} / \mathrm{MoO}_{2}$} & $2 \mathrm{MoO}_{2}+\mathrm{O}_{2} \rightarrow 2 \mathrm{MoO}_{3}$ & -306 & -195 \\
\hline & $\mathrm{C}+2 \mathrm{MoO}_{3} \rightarrow \mathrm{CO}_{2}+2 \mathrm{MoO}_{2}$ & -88 & -200 \\
\hline \multirow{2}{*}{$\mathrm{SnO}_{2} / \mathrm{SnO}$} & $2 \mathrm{SnO}+\mathrm{O}_{2} \rightarrow 2 \mathrm{SnO}_{2}$ & -590 & -640 \\
\hline & $\mathrm{C}+2 \mathrm{SnO}_{2} \rightarrow \mathrm{CO}_{2}+2 \mathrm{SnO}$ & +196 & +244 \\
\hline \multirow{2}{*}{$\mathrm{WO}_{3} / \mathrm{WO}_{2}$} & $2 \mathrm{WO}_{2}+\mathrm{O}_{2} \rightarrow 2 \mathrm{WO}_{3}$ & -502 & -494 \\
\hline & $\mathrm{C}+2 \mathrm{WO}_{2} \rightarrow \mathrm{CO}_{2}+2 \mathrm{WO}_{3}$ & +108 & +99 \\
\hline \multirow{2}{*}{$\mathrm{NaNO}_{3} / \mathrm{NaNO}_{2}$} & $2 \mathrm{NaNO}_{2}+\mathrm{O}_{2} \rightarrow 2 \mathrm{NaNO}_{3}$ & -200 & - \\
\hline & $\mathrm{C}+2 \mathrm{NaNO}_{3} \rightarrow \mathrm{CO}_{2}+2 \mathrm{NaNO}_{2}$ & -194 & - \\
\hline \multirow{2}{*}{$\mathrm{Na}_{2} \mathrm{SO}_{4} / \mathrm{Na}_{2} \mathrm{~S}$} & $\frac{1}{2} \mathrm{Na}_{2} \mathrm{~S}+\mathrm{O}_{2} \rightarrow \frac{1}{2} \mathrm{Na}_{2} \mathrm{SO}_{4}$ & -502 & -482 \\
\hline & $\mathrm{C}+\frac{1}{2} \mathrm{Na}_{2} \mathrm{SO}_{4} \rightarrow \mathrm{CO}_{2}+\frac{1}{2} \mathrm{Na} 2 \mathrm{~S}$ & +108 & +86 \\
\hline
\end{tabular}

る。無炎燃焼部の熱源としては，酸化剂生成部より発生した 高温熱をカスケード利用することが挙げられる。また製鉄の 高炉や金属の精錬炉，鵼業用のキルンなどの他の工業装置か ら発生する排熱が挙げられる。また溶融炭酸塩, 硝酸塩, 塩 化物の溶融塩をそれぞれ利用する太陽熱の潜熱蓄熱材とする 研究が進められている ${ }^{29)}$ 。溶融塩を反応媒体および熱媒体と して利用することで, 太陽エネルギーを溶融塩に集熱して低 温熱源として利用の技術を確立できれば，太陽熱エネルギー の有効利用になると考えられる。

ケミカルヒートポンプの能力を式に従って計算した。

$$
\text { ケミカルヒートポンプの能力 }=\frac{\text { 酸化剂生成反応の発熱量 }\left(\Delta \mathrm{H}^{0} \mathrm{OX}\right)}{\text { 燃焼熱量 }\left(\Delta \mathrm{H}^{0} \mathrm{COMB}\right)}
$$

ケミカルヒートポンプ作用のある酸化還元系について, 炭素 を燃料としたときのケミカルヒートポンプの能力を計算した 結果を Table 3 に示す。 $\mathrm{SnO}_{2} / \mathrm{SnO}$ で能力が最も高く, 酸化剂 生成反応の発熱量は燃焼熱量の 1.62 倍である。これらの酸化 還元対を利用することで, 従来の燃焼によりも, 熱エネルギー を有効に活用できる可能性があると考えられる。
Table 3 Chemical heat pump effects of Molten Salt Redox Combustion System with carbon as fuel

\begin{tabular}{|c|c|c|c|c|}
\hline $\begin{array}{c}\text { Redox } \\
\text { System } \\
\text { Ox/Red }\end{array}$ & $\begin{array}{l}\triangle \mathrm{H}^{0} \mathrm{FUEL} \\
\text { at } 500^{\circ} \mathrm{C} \\
(\mathrm{kJ} / \mathrm{mol})\end{array}$ & \begin{tabular}{|c|}
$\Delta \mathrm{H}^{0} \mathrm{OX}$ \\
at $1000^{\circ} \mathrm{C}$ \\
$(\mathrm{kJ} / \mathrm{mol})$
\end{tabular} & $\begin{array}{l}\text { Heat pump effect } \\
\Delta \mathrm{H}^{0} \mathrm{OX} / \Delta \mathrm{H}^{0} \mathrm{COMB}\end{array}$ & $\begin{array}{l}\text { Energy } \\
\text { density } \\
(\mathrm{kJ} / \mathrm{kg})\end{array}$ \\
\hline $\mathrm{SnO}_{2} / \mathrm{SnO}$ & +196 & -640 & 1.62 & -2375 \\
\hline $\mathrm{Fe}_{2} \mathrm{O}_{3} / \mathrm{FeO}$ & +181 & -558 & 1.41 & -1997 \\
\hline $\mathrm{WO}_{3} / \mathrm{WO}_{2}$ & +108 & -494 & 1.25 & -1144 \\
\hline $\mathrm{Na}_{2} \mathrm{SO}_{4} / \mathrm{Na}_{2} \mathrm{~S}$ & +108 & -482 & 1.22 & -12351 \\
\hline $\mathrm{NiO} / \mathrm{Ni}$ & +78 & -467 & 1.18 & -3978 \\
\hline $\mathrm{CoO} / \mathrm{Co}$ & +74 & -467 & 1.18 & -3962 \\
\hline $\mathrm{C}+\mathrm{O}_{2} \rightarrow \mathrm{CO}_{2}$ & \multicolumn{2}{|c|}{$\Delta \mathrm{H}^{0} \mathrm{COMB}=-395$} & 1.00 & -32939 \\
\hline
\end{tabular}

\section{5. 溶融塩レドックス燃焼システムの特徵}

\section{1 純粋な二酸化炭素の回収}

本システムでは，燃焼に必要な空気は酸化剂生成部へと，燃 料は無炎燃焼反応部へと, 別々に投入される。そして燃焼の 生成物である二酸化炭素と水蒸気は無炎燃焼部より無炎燃焼 反応部より排出される。このとき空気中の窒素が混入するこ とはない。この排出ガスから熱を回収した後, 凝縮器で排出 ガス中に含まれる水蒸気を水として分離することで, 純粋な 二酸化炭素を回収できる。

従来法では, 排出ガス中からの二酸化炭素の分離に際して 消費されるエネルギーやコストの低減が課題となっていたが, 
本システムでは分離を必要とせず直接回収できるため，この ような問題を回避できる。回収した二酸化炭素を地中や海洋 への固定・隔離する技術開発が行われている。また現在は研 究段階ではあるが、メタノールなどの有用化学物質の合成原 料やバイオリアクターによる光合成の原料としての利用が挙 げられる。

\section{$5.2 \mathrm{NOx}, \mathrm{SO}, \mathrm{HCl}$, ダイオキシンの発生の抑止}

従来の火炎を伴って空気と燃料を直接反応させる燃焼方法 では, 過熱空気から発生するThermal NOxや窒素分, 硫黄分, 塩素分を含吉燃料の燃焼で形成する窒素酸化物, 硫黄酸化物, 塩化水素, ダイオキシンの発生が問題である。本システムで は，溶融塩を適切に選択することにより燃焼の副生成物であ るこれらの有害物質の発生を抑止することが可能である。例 として, 溶融塩に溶融塩酸化法で報告されている炭酸塩の場 合を用いて説明する。

燃焼により発生する壆素酸化物には，火炎により $1500^{\circ} \mathrm{C}$ 以 上に熱せられた空気中の窒素と酸素が反応して形成される Thermal NOx と, 燃料中の窒素成分が酸化されて形成する Fuel NOxに大別される。本システムでは, 溶融塩中の酸化還 元反応を利用し, これらの反応は $1000^{\circ} \mathrm{C}$ 以下で進行すること から Thermal NOxは原理上発生しない。また燃料に含まれる 窒素成分は, 無炎燃焼反応において溶融炭酸塩と反応するこ とで無害な硝酸塩として溶融塩中に捕捉することができ，環 境に直接排出することを防ぐことが可能となる。窒素成分を 含む炭化水素の無炎燃焼反応を反応 $(10)$ に示す。

$$
\begin{aligned}
\mathrm{CaH}_{b} \mathrm{~N}_{c} & +\frac{c}{2} \mathrm{M}_{2} \mathrm{CO}_{3}+\frac{2 a+\frac{b}{2}+\frac{5}{2} c}{m} \mathrm{RO}_{m} \\
& \rightarrow\left(a+\frac{c}{2}\right) \mathrm{CO}_{2}+\frac{b}{2} \mathrm{H}_{2} \mathrm{O}+\mathrm{CMNO}_{3}+\frac{2 a+\frac{b}{2}+\frac{5}{2} c}{m} R
\end{aligned}
$$

従来の燃焼方法では，硫黄成分を含む石炭やゴムなどを燃 焼すると，硫黄酸化物が発生することが問題である。本シス テムでは, 燃料中の硫黄分を無炎燃焼反応において溶融炭酸 塩に反応することで, 無害な硫酸塩として捕捉する。硫黄成 分を含む炭化水素の無炎燃焼反応は反応 (11)により示される。

$$
\begin{aligned}
\mathrm{CaH}_{b} \mathrm{~S}_{c} & +\mathrm{cM}_{2} \mathrm{CO}_{3}+\frac{2 a+\frac{b}{2}+3 c}{m} \mathrm{RO}_{m} \\
& \rightarrow(a+c) \mathrm{CO}_{2}+\frac{b}{2} \mathrm{H}_{2} \mathrm{O}+\mathrm{cM}_{2} \mathrm{SO}_{4}+\frac{2 a+\frac{b}{2}+3 c}{m} R
\end{aligned}
$$

有機ハロゲン化物であるPVCやPCBなどの廃棄物や燃料中 に含まれるハロゲン成分は，従来の燃焼法では人体に有害性 があり，かつ燃料装置の腐食を促進する塩化水素やダイオキ シンの発生の原因となる。本システムを用いれば，八ロゲン 成分は溶融炭酸塩と反応することで, 無害なハロゲン化物を 形成し溶融塩中に捕捉される。例えば, 塩素成分を含む炭化 水素では反応 $(12)$ で示される。

$$
\begin{aligned}
\mathrm{CaH}_{b} \mathrm{Cl} l & +\frac{c}{2} \mathrm{M}_{2} \mathrm{CO}_{3}+\frac{2 a+\frac{b}{2}+\frac{c}{2}}{m} \mathrm{RO}_{m} \\
& \rightarrow\left(a+\frac{c}{2}\right) \mathrm{CO}_{2}+\frac{b}{2} \mathrm{H}_{2} \mathrm{O}+\mathrm{cMCl}+\frac{2 a+\frac{b}{2}+\frac{c}{2}}{m} R
\end{aligned}
$$

溶融炭酸塩を基礎とした溶融塩を用いた廃棄物の処理に研

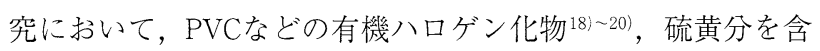
むゴム 16) 18),22) やイオン交換樹脂 ${ }^{17)}$ を溶融塩により処理した 結果，硫黄分やハロゲン成分は溶融塩中に捕捉されて，排出 ガス中の塩化水素や硫黄酸化物は数ppm未満であり検出限界 以下であったこと, 窒素酸化物の濃度は数十一数百 $\mathrm{ppm}$ 程度 の比較的低濃度であったことが報告されている。

本システムであれば，石炭や廃棄物は一日，液体である溶 融塩中を通過するため，それらに含まれる酸化アルミニウム， 酸化ケイ素, 酸化鉄, 酸化カルシウム, 酸化マグネシウムを 成分とする灰分は，溶融塩に捕捉される。そのため集じん装 置を必要とせずに，灰分が環境に放出されることはない。た たし，灰分は溶融塩中に溜まると溶融塩の融点の上昇や，粘 度の増大による流動性の低下といった問題を引き起こす。そ のため, 溶融塩より灰分を取り除くための溶融塩浄化器が必 要となると考えられる。溶融塩からの灰分の分離方法として は，塩を泠却した後，水に溶かして，フィルターにより不溶 性の扊分を取り除く方法が考えられる。溶融塩の成分として は炭酸塩や硫酸塩が考えられるが，これらは比較的水への溶 解度が大きく，それに対して灰分は水に対して不溶性である ことを利用するものである。水溶液を滤過した後，蒸発させ ることで清浄な塩が得られる。

\section{3 燃料の形状や熱量に対する対応性}

$\mathrm{Na}_{2} \mathrm{O}_{2}$ を除く酸化還元対に扔いて、発熱量は無炎燃焼反応よ りも酸化剂生成反応の方が大きいことがTable 2 から分かる。 そのため燃料が直接関与しない酸化剂生成部で高温の熱工ネ ルギーを取り出すことが可能になる。そのため無炎燃焼反応 で必要な反応速度が得られるのであれば，発熱挙動に影響を 与えるのは空気の導入量および還元体の導入量のみであり， 燃料の種類や状態，形状が影響することはない。そのため不 均一な混合燃料や異なるエネルギー密度を持った燃料を同時 に投入しても，安定に発熱速度を得ることが可能である。燃 料が気体, 液体, 固体のいずれの状態であっても, 溶融塩中 で酸化体と反応させることが可能である。

\section{6. 結 言}

我々は燃焼による高温の発熱を利用すると同時に, 発生す る二酸化炭素を純粋な状態で回収できるシステムとして, 溶 融塩レドックス燃焼システムを提案した。本システムは, 酸 化還元媒体を含む溶融塩中で生じる酸化還元反応を利用して， 酸化剂生成反応と無炎燃焼反応の二つの反応により，燃焼を 進行するものである。溶融塩中で反応が進行するため, 火炎 を伴わない燃焼となる。窒素酸化物や硫黄酸化物などの污染 物質が発生しないことや, 石炭や木材などの多様な燃料を効 率良く利用できることなどの従来の燃焼方法にはない特徴を 創出できることが見込まれた。

本システムの実現には, 溶融塩中における酸化剂生成反応 と無炎燃焼反応とを確立することが必要である。このために は，空気により酸化剤を生成し，その酸化剤が然料を酸化す 
る能力のある酸化還元対を探索した。そこで，酸化還元対の 酸化力を, 酸素の酸化力を基準として, 空気拉よび燃料と比 較することで，条件を満たすことのできる酸化還元対を見出 した。

同じ燃料を燃焼する場合でも，それぞれの酸化還元対によ り, 二つの反応の発熱挙動は大きく異なる。特に $\mathrm{SnO}_{2} / \mathrm{SnO}$, $\mathrm{Fe}_{2} \mathrm{O}_{3} / \mathrm{FeO}, \mathrm{WO}_{3} / \mathrm{WO}_{2}, \mathrm{Na}_{2} \mathrm{SO}_{4} / \mathrm{Na}_{2} \mathrm{~S}$ な゙は, 無炎燃焼反応が 吸熱となると共に，酸化剂生成反応に扔ける発熱量が通常の 燃焼熱よりも大きくなることが予測された。これらの酸化還 元対を本システムに適用した場合，燃焼と同時にケミカル ヒートポンプ作用を利用することで，従来の燃焼方法よりも 効率よく熱エネルギーを活用できることを見出した。

\section{文 献：References}

1) 平成 14 年 3 月, $N E D O$ - (株) 富士総合研究所, “温暖化に おける二酸化炭素隔離技術の政策的位置付けに関する調查 研究”，報告書 51401148-0 (2002)

2）平成10年 3 月, NEDO・(株)ジャパンエナジーリサーチセ ンター, “石油，重質油等化石燃料の酸素燃焼に上る燃焼 エネルギーの高効率化利用と高濃度 $\mathrm{CO}_{2}$ 回収に関する調 查”，報告書 NEDO-GET-9715 (1998)

3) Richiter, H. J., and Knoche, K. F., ACS Symp. Ser, 235, 71 (1983)

4) Ishida, M., and Jin, H., J. Chem. Eng. Japan, 27, 296 (1994)

5) Lyngfelt, A., Leckner, B., and Mattisson, T., Chem. Eng. Sci., 56, $3101(2001)$

6）朝倉祝治, 東海林裕一, 鵜木和夫, 永山賢一, 吉岡律夫, 日本国特許 2001-173938(2001)

7) Greenberg, J., US patent $3647358(1972)$

8) Yosim, S. J., McKenzie, D. E., Hills, W., Grantham, L. F., Calif, C., Birk, J. R., US patent 3845190 (1974)

9) Gay, R. L., Guon, G. J., Newcomb, J. C., US patent 5348689 (1993)

10) William, A. B., Ravindra, S. U., Cesar, O. P., US patent 5434335 (1995)

11) Weimer, A. W., Czerpak, P. J, Hilbert, P. M., US patent 6565820 (2000)

12) Dunks, G. B., Stelman, D., Yosim, S. J., Carbon, 21, 365(1980)
13) Dunks, G. B., Stelman, D., Yosim, S. J., Inorg. Chem., 21, 108 (1982)

14) Dunks, G. B., Stelman, D., Inorg. Chem., 22, 2168 (1983)

15) Dunks, G. B., Inorg. Chem., 23, 828(1984)

16) Gay, R. L., Barclay, K. M., Grantham, L. F., Yosim, S. J., CHEMTECH, 11 (9), 572(1981)

17) Hsu, P. C., Foster, G. F., Ford, T. D., Wallman, P. H., Watkins, B. E., Pruneda, C. O., and Adamson, M. G., Waste Management, 20, 363(2000)

18) Yang, Hee-Chul., Cho, Yong-Jun., Yun, Jong-Sung., Kim, Joon-Hyung., Can. J. Chem. Eng., 81 (3-4), 713 (2003)

19) Grantham, L. F., McKenzie, D. E., Richards, W. L., Oldenkamp, R. D., Proceedings of the ERDA.Air Cleaning Conference, 14 (1), 17 (1976)

20) McKenzie, D. E., Grantham, L. F., Paulson, R. B., Manage, LowLevel Radioact. Waste Symp., 333(1979)

21) Lacchia, M. B., Shaw, B. D., Combustion Science and Technology, 139(1-6), 59(1998)

22) Yosim, S. J., Barclay, K. M., Grantham, L. F., ACS Symp. Ser, 73, 118(1978)

23) Stewart, A., Schnittgrud, G., Journal of Energetic Materials, 13 (3\&4), 213(1995)

24) Lefrancois, P. A., Barclay, K. M., Skaperdas, G. T., Adv. Chem. Ser, 69, 64(1967)

25）朝倉祝治, 安全工学, 21, 130(1982): Asakura, S., Journal of Japan Society for Safety Engineering, 21, 130 (1982)

26) Yosim, S. J., Grantham, L. F., McKenzie, D. E., Stegman, G. C., Adv. Chem. Ser, 127, 174(1973)

27）熱力学データベース WG，“パソコン用熱力学データベー 久 MALT2”vol. 1.05，(科学技術社)，(1992)

28）朝倉祝治, 島野哲, 藏屋英介, 東海林裕一, 吉岡律夫, 溶 融塩㧍よび高温科学，44(1)，51-64(2001): Asakura, S., Shimano, S., Kuriya, E., Shoji, Y., Yosioka, R., Yoyuen oyobi Koon Kagaku, 44 (1), 51-64(2001)

29）伊藤靖彦 編，溶融塩の応用，(アイピーシー), p. 221 (2003) :Ito, Y., ed., Yoyuen no Ouyou, (Industrial Publishing \& Consulting, Inc.), p. 221 (2003) 